\title{
REVIEW Studies of Human Airways in vitro: A Review of the Methodology
}

\author{
Anthon R. Hulsmann and Johan C. de Jongste \\ Department of Pediatrics, Division of Pediatric Respiratory Medicine, \\ Sophia Children's Hospital Rotterdam. The Netherlands
}

\begin{abstract}
The pathophysiology of human airway narrowing is only partly understood. In order to gain more insight in the mechanisms of human lung diseases and potential beneficial therapeutic agents, adequate models are needed. Animal airway models are of limited value since lung diseases such as asthma and chronic obstructive pulmonary disease (COPD) are unique to humans and because the mechanisms of airway narrowing differ between species. Therefore, it is important to perform studies on human isolated airways. We describe the models that have been developed to study airway function in vitro, emphasizing human airway preparations. The easily prepared airway strip and ring preparations are described first. The potential damage during preparation and the interference with airway structure are important drawbacks in these preparations. Lung parenchymal strips, described next, were designed in order to study responsiveness of small airways. However, parenchymal strips are anatomically complex, and responsiveness is determined by the relative amounts of airway and vascular smooth muscle. The lack of reproducibility between species and even within one animal limits their usefulness. Airway tube preparations, in which luminal and serosal stimulation can be separated, enable us to study the modulatory role of the airways epithelium in vitro. Furthermore, airway compliance can be measured. In the isolated perfused lung preparation, relationships between the airways and the vascular system are preserved and the interaction between these two systems can be studied. Weight gain due to fluid extravasation is a problem in this model which has not been used yet to study human lungs in vitro. Next, methodological aspects such as tissue handling and storage, recording of responses, removal of the epithelium, and electrical field stimulation are discussed in some detail. Although animal airways tissue can be studied immediately after removal, human tissue is often obtained with some delay. However, this seems tenable since electron microscopy of lung tissue obtained at autopsy showed that recovery of the preparation occurs during incubation of carbogenated Krebs-Henseleit $(\mathrm{K}-\mathrm{H})$ buffer. Dissected airways can be stored overnight in cooled $\mathrm{K}-\mathrm{H}$ buffer until up to $55 \mathrm{hr}$ after resection without losing viability. Commonly used physiological salt solutions which bath the tissue contain osmotic molecules, ions important for contractility, glucose as a substrate, and a bicarbonate-carbon dioxide buffer. In studies of isolated perfused lungs, a colloid should be added in order to prevent edema. The responses of isolated airways strips and rings are recorded under isometric or isotonic conditions. Smooth muscle contraction in vivo, however, is auxotonic; the elastic load on the smooth muscle increases during airway narrowing. In perfused airway tubes responsiveness is measured under auxotonic conditions as a change in perfusion pressure or flow. Next, removal of epithelium from isolated airways is discussed. Although mechanical denudation is widely used, more physiological methods that mimic the epithelial damage found in asthma may well be preferable and these methods are described in some detail. Finally, the methodology of electric field stimulation (EFS) is described. EFS is delivered via electrodes suspended in the organ bath. According to the stimulus parameters chosen, autunomic nerves or smooth muscle cells are stimulated. An important side effect of EFS is the generation of oxygen radicals in carbogenated K-H buffer which may alter airway tone directly, or oxidize agonists added to the organ bath. It is concluded that although our knowledge of the pathophysiology of airway disease is rapidly increasing, the role of the bronchial circulation is poorly understood. Therefore, the development of a method to study the interaction between the ventilatory and the vascular systems in the isolated human lung is a major challenge.
\end{abstract}

Keywords: Isolated airways; Airways smooth muscle; Airway epithelium; Electrical ficld stimulation; Airway responsiveness; Bronchial circulation

Address reprint requests to Dr. Johan C. de Jongste, MD PhD, Sophia Children's Hospital, Department of Pediatrics, P.O. Box 70029, 3000 LL Rotterdam, the Netherlands. Address after November 23, 1993; Sophia Children's Hospital, Dept. of Pediatrics Subdivision Pediatric Respiratory Medicine, Dr. Molewaterplein 60,3015 GJ, Rotterdam, the Netherlands.

Received March 1993; revised and accepted July 1993.

Journal of Pharmacological and Toxicological Methods 30, 117-132 (1993)

(C) 1993 Elsevier Science Publishing Co.. Inc..

655 Avenue of the Americas. New York. NY 10010

$1056-8719 / 93 / \$ 6.00$ 


\section{Introduction}

The pathophysiology of human airway narrowing that characterizes asthma and chronic obstructive pulmonary disease (COPD) is only partly understood. Inflammation of the lung, especially of the airways, is found both in asthma (Djukanovic et al., 1990) and in COPD (Cosio et al., 1980) and may play a pivotal role in the development of bronchial hyperresponsiveness in asthma (Juniper et al., 1981; Cockcroft, 1988) and COPD (Yan et al., 1985; Bahous et al., 1985). In order to gain more insight into the underlying processes of human lung diseases, animal models have been developed. In most of these animal models, the immediate (IAR) and the late asthmatic reaction (LAR) can be induced by allergen challenge (Michoud et al., 1978; Wanner and Abraham, 1982; Hirshman, 1985; Snapper, 1986; Hayes et al., 1992). However, important differences between species exist (Snapper, 1986). Therefore, it is important to study pathophysiological and pharmacological aspects of human airway disease in human isolated airways. Most in vitro studies of human airways have been performed on tissue derived from smokers with or without COPD who were operated on because of bronchial malignancy. These studies have shown that the sensitivity of isolated airways is not related to the sensitivity to inhaled histamine or methacholine in nonasthmatic subjects (Vincenc et al., 1983; Taylor et al., 1985; Cerrina et al,. 1986; de Jongste et al., 1987a) indicating that airway hyperresponsiveness may not result from an intrinsic abnormality of airways smooth muscle. In the rarely available airways of asthmatic patients increased (Schellenberg and Foster, 1984; de Jongste et al., 1987b; Bai, 1990) as well as decreased (Goldie et al., 1986; Whicker et al., 1988) responses to contractile agonists have been reported.

These apparently contradictory results, that may well be due to methodological factors (de Jongste et al., 1989), and the lack of correlation between in vitro and in vivo measurements illustrate that in vitro data should be interpreted with caution.

Nevertheless, the study of pharmacology of human airways in vitro may provide insight into the pathogenesis of human airway disease. For instance, the role of the airways epithelium (Flavahan et al., 1985; Aizawa et al., 1988; Fedan and Frazer, 1992) and the nonadrenergic, noncholinergic (NANC) nervous system (Richardson and Béland, 1976; de Jongste et al., 1987c; Ellis and Undem, 1992) in airway responsiveness have been studied in detail in isolated airways. Furthermore, studies in vitro offer the opportunity to test the effects or side effects of novel pharmacological compounds potentially acting on lung tissue. The relaxant effects of the potassium channel opener cromokalim (Cortijo et al., 1992), originally developed for the treatment of hypertension, and of the phosphodiesterase inhibitors rolipram and SK\&F 94120 (Belvisi et al., 1992a) on human isolated airways are examples of such in vitro studies.

A variety of models for animal and human isolated airways in vitro has been described since Williams" (1840) demonstration of the contractile mechanisms in isolated lungs. This review will briefly discuss these models, their historical backgrounds, their applications, and their restrictions. Furthermore, methodological aspects such as preparation and overnight preservation, epithelium removal, and electrical field stimulation are discussed, emphasizing human airways.

\section{Isolated Airway Preparations}

\section{Airway Strip and Ring Preparations}

In 1912 an isolated large airway preparation was described by Trendelenburg. Isotonic recordings were made in bovine tracheal rings with or without cartilage, and the bronchodilator effects of caffeine, adrenaline, and atropine were demonstrated (Trendelenburg, 1912). In order to measure the responses of tracheal muscle of small animals in vitro, Castillo and De Beer (1947) used a chain of 10-12 tracheal rings. By means of the additive responses of the rings in the chain preparation, they were able to demonstrate bronchoactive effects of various drugs. The same principle was applied to human central bronchi (Hawkins and Schild, 1951; Rosa and McDowell, 1951). However, the tracheal chain is a laborious preparation that requires a lot of airway tissue, and each connecting knot is a potential source of tissue damage and mechanical instability. Several years later, spirally cut airway strips from animals (Patterson, 1958; Constantine, 1965; Persson and Ekman, 1976) and humans (Persson and Ekman, 1976; Brink et al., 1980; Goldie et al., 1982) were described. These were easier to prepare, but the preparation also caused tissue damage. The development of sensitive transducers made it possible to record isotonic shortening or isometric force development in strips or rings of dissected animal (Persson and Ekman, 1976; Hooker et al., 1977; Advenier et al., 1985) and human (Persson and Ekman, 1976; Finney et al., 1985; de Jongste et al., 1985; Jongejan et al., 1988) small airways. In Figure 1, the different airway strip and ring preparations are shown schematically. Theoretically, airway ring preparations have advantages over airway strips: the contraction of a ring is directly related to airway narrowing and, furthermore, the configuration of the smooth muscle bundles is largely preserved. A practical advantage is that only a small piece of tissue is needed. $A$ disadvantage of the airway strips and -ring preparations is the inability to 


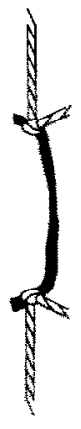

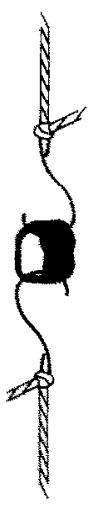

B

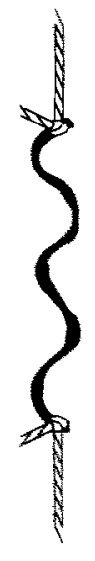

$\mathrm{C}$

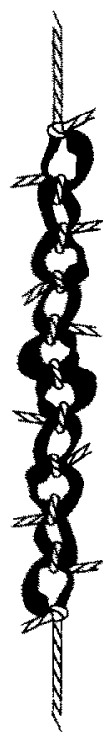

D
Figure 1. Schematic representation of the airway strip (A), airway ring (B), spiralized airway strip (C), and airway chain preparation (D).

stimulate the mucosal or the serosal side selectively. Figure 2 displays an airway ring preparation in a conventional double-jacketed organ bath.

\section{Lung Parenchymal Strips}

The lung parenchymal strip was developed by Lulich et al. (1976) as an in vitro preparation to evaluate the actions of drugs on peripheral airways. Thin strips (approximate dimensions $20 \times 3 \times 3 \mathrm{~mm}$ ) were dissected from a lung lobe and studied in a conventional organ bath. The preparation has been widely used in studies of both laboratory animal (Drazen et al., 1978; Chand et al., 1979; Kleinstiver and Eyre, 1980; Omini et al., 1990) and human (Ghelani et al., 1980; Finney et al., 1984; Saga et al., 1984) lungs. Marked differences in responsiveness to various agents of the smooth muscle of central airway strips and lung parenchymal strips were found, and it was assumed that the drug-induced effects in parenchymal strips reflected the responses of smooth muscle of small airways present in the bronchioles and alveolar ducts (Lulich et al., 1976; Drazen et al., 1978; Chand et al., 1979; Ghelani et al., 1980; Finney et al., 1984). However, since the responses of parenchymal strip preparations to sympathomimetic drugs were not consistent between species and even within a single animal, the involvement of nonairway components such as vascular smooth muscle (Mirbahar and Eyre, 1980; Goldie et al., 1980) and, probably, interstitial contractile cells (Kapanci et al.,

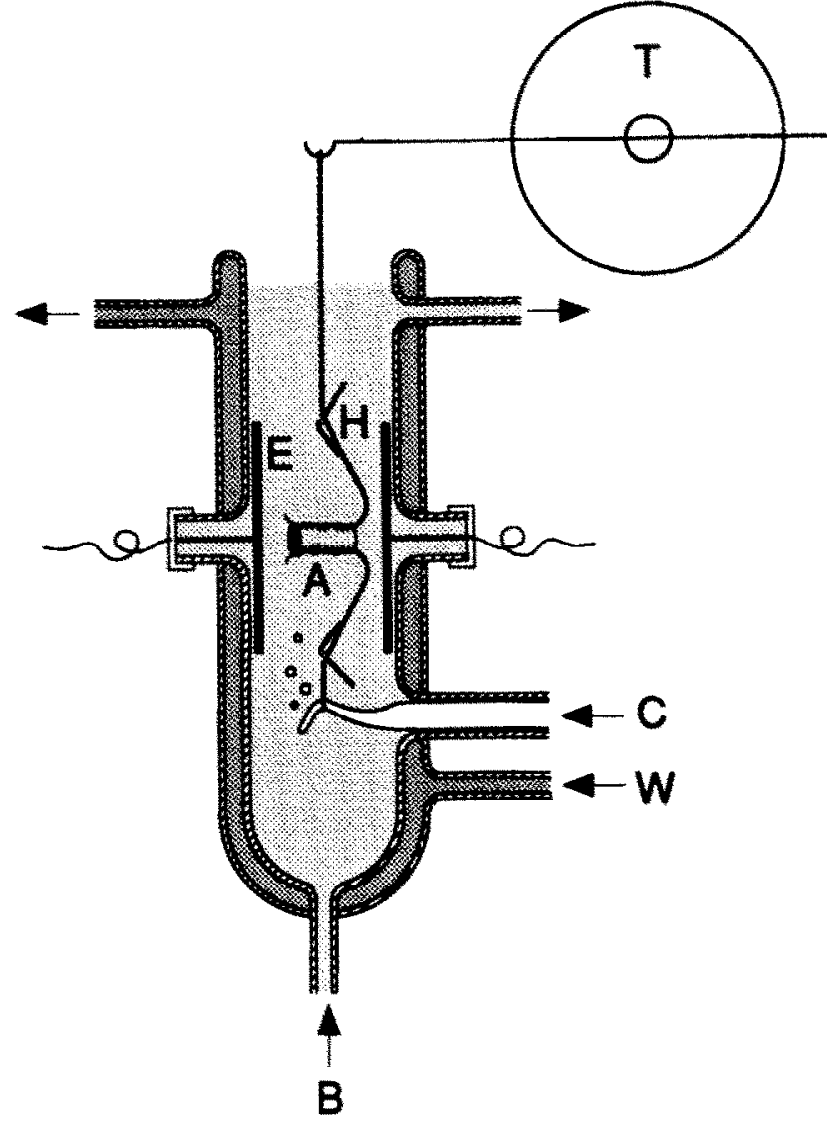

Figure 2. Schematic representation of an airway ring preparation mounted in a double-jacketed, glass organ bath. A, airway preparation; $B$, buffer supply; C, carbogen supply; $\mathrm{E}$, platinum electrodes; $H$, stainless steel hookes; $T$, isotonic transducer; W, warm $\left(37^{\circ} \mathrm{C}\right)$ water supply.

1974) was suggested. Indeed, Bertram et al. (1983) showed that the type and size of responses of human parenchymal strips to the sympathicomimetic drugs serotonin and noradrenaline depended on the relative amounts of blood vessels and larger airways present in the airway preparation. Thus, noradrenaline will induce a contractile response in parenchymal strips containing more than twice as much vascular smooth muscle as airway smooth muscle, and noradrenaline will induce a relaxation when this ratio is lower than twofold (Figure 3). These relative amounts of the contractile components were determined with stereological analysis, a method that enables estimates of different parameters in a 3-dimensional body (Weibel, 1979), and a large variability in composition was shown between strips obtained from the same lung (Bertram et al., 1983). Similarly, the disparity of responses in different species can be explained by differences in composition; a slice of rat lung will comprise larger airways and blood vessels than would a similarly sized slice of human lung (Eyre and Mirbahar, 1981; Goldie et al., 


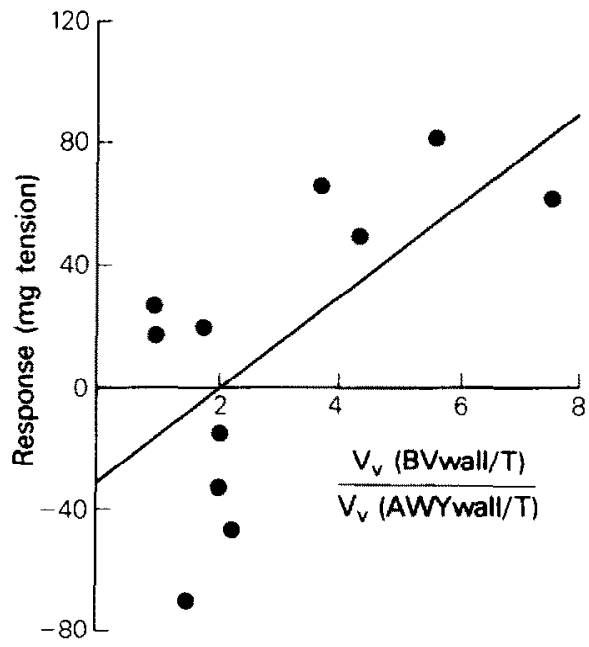

Figure 3. Relationship between the ratio of the volume densities of blood vessel wall to airway wall in tissue $\left(V_{v}(B V w a l l /\right.$ $\mathrm{T}) / \mathrm{V}_{\mathrm{v}}(\mathrm{AWY}$ wall/T), and responses of human isolated lung parenchyma strips to noradrenaline $(r=0.65, p<0.05)$. (Reproduced with permission of Bertram et al., 1983.)

1984). It appears, therefore, that the anatomical complexity of the parenchymal strip restricts its value as a method to study small airway pharmacology.

\section{Isolated Perfused Airways}

The airway epithelium may modulate airway responsiveness through 1) the release of relaxing factors (Farmer and Hay, 1991), 2) the breakdown of agonists (Advenier et al., 1988; Devillier et al., 1988), and 3) acting as a physical barrier (Munakata and Mitzner, 1991). In human airway strips and rings, however, only a 1.5 to 2.5 -fold increase in sensitivity to contracting agonists is found after mechanical removal of the epithelium (Raeburn et al., 1986a; Aizawa et al., 1988; Jongejan et al., 1991) probably because the stimulus reaches the smooth muscle not only via the mucosal side but also via the serosal side and the cut surface. Therefore, models have been developed that allow independent stimulation of rodent-intact tracheas and pig and human bronchial segments from the serosal and the mucosal side selectively. These airway "tube preparations" were perfused under conditions of constant flow (Munakata et al., 1988; Mitchell et al., 1989; Yang et al., 1991; Fedan and Frazer, 1992) or constant pressure (Mitchell et al., 1989; Sparrow and Mitchell, 1991; Omari et al., 1993), and responsiveness was measured as a change in perfusion pressure or flow, respectively. In these intact perfused airway preparations, the sensitivity to luminally applied contractile and relaxing agonists was much lower (over 30-fold) than that to serosally applied agonists. These differences were abolished after mechanical rubbing of the epithelium, indicating that the effect was caused by the presence of epithelium.

We developed a similar model to investigate the modulatory role of the epithelium in human peripheral airways (Hulsmann et al., 1992). Human isolated peripheral airway tubes were perfused with Krebs-Henseleit solution at a constant pressure of 6 $\mathrm{cm}_{2} \mathrm{O}$ (Figure 4), and responsiveness was measured as a change in flow. Accurate and reproducible measurements of sensitivity to metacholine were obtained. With this method we demonstrated a much greater modulatory role of the epithelium in human perfused peripheral airways than in peripheral airway strips (Hulsmann et al., 1993a). Apart from studying the modulatory role of the epithelium, airway tube preparations have been used to study other factors that determine airway narrowing such as preload and airway compliance. The effect of preload on airway narrowing has been studied in rabbit, pig, and human isolated airways. The transmural pressure in closed airway segments was varied between -10 and $+30 \mathrm{~cm} \mathrm{H}_{2} \mathrm{O}$, and the pressure change to field stimulation was recorded. It appeared that both the presence of cartilage and the transmural pressure determine the preload (and hence force) of the smooth muscle (Moreno and Paré, 1989; Sparrow et al., 1992; Figure 5).

Gunst and Stropp (1988) determined pressure-volume relationships in canine bronchi by measuring bronchial transmural pressure changes during inflation and deflation of the airway preparation with $\mathrm{K}-\mathrm{H}$ solution. The compliance of contracted airways was lower than that of relaxed airways. Large airways contracted with acetylcholine $\left(10^{-3} \mathrm{M}\right)$ developed pressures $>30$ $\mathrm{cm} \mathrm{H}_{2} \mathrm{O}$ only near their maximal volumes, whereas small airways developed similar pressures at a much wider volume range (Figure 6). Furthermore, small airways were able to constrict to closure but large airways constricted only to $30 \%$ of maximal volume. These differences are probably due largely to differences in orientation of the smooth muscle tissue and in the amount of cartilage between large and small airways (Gunst and Stropp, 1988).

\section{Isolated Perfused Lungs}

The lung is supplied by both the pulmonary circulation and the tracheo-bronchial circulation. The tracheo-bronchial circulation may be important in the pathogenesis of asthma because of its involvement in the influx of inflammatory cells into the airways, in the development of airway wall edema, and in the clearance of bronchoactive mediators and inhaled drugs (Persson, 1986; Deffebach et al., 1987; Deffebach and Widdicombe, 1991; Widdicombe, 1992). In addition, 
Figure 4. Schematic presentation of the human perfused airway preparation. The transmural pressure is maintained at $6 \mathrm{~cm}$ $\mathrm{H}_{2} \mathrm{O}$. B, buffer supply: $\mathrm{C}$, stainless steel cannula; $O$, organ bath; $S$, airway segment; $T$, electromagnetic transducer. (Reproduced with permission of Hulsmann et al., 1992.)

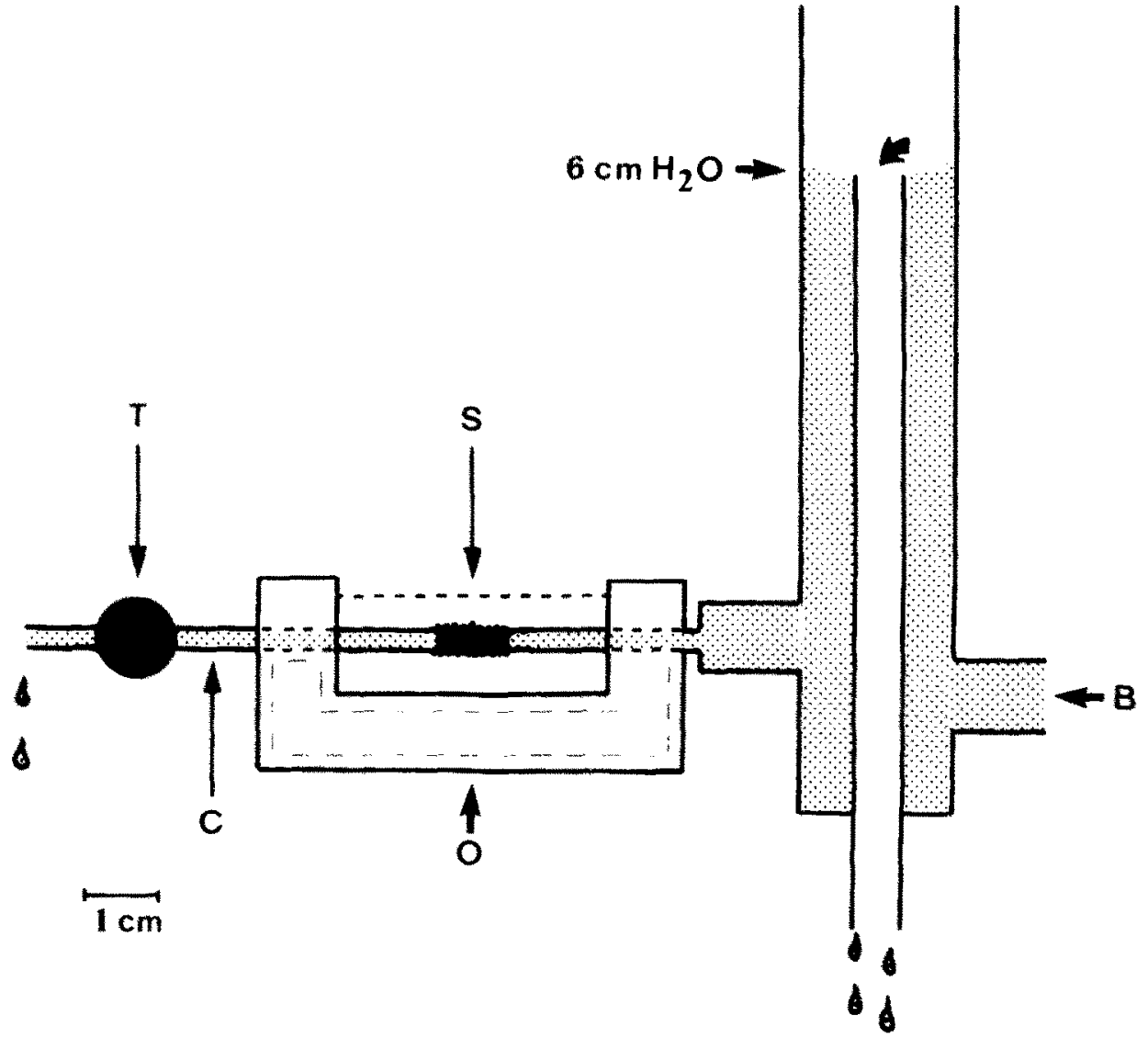

Figure 5. Relationship between transmural pressure and response to EFS of bronchial segments from pig ( $3 \mathrm{~mm}$ i.d.) and human ( $4 \mathrm{~mm}$ i.d.) lung. Closed segments were activated by electrical field stimulation $(20 \mathrm{~Hz}, 0.5 \mathrm{~ms}, 60 \mathrm{~V})$, and the increase in pressure was recorded via a transducer attached to a T-piece at one end of the preparation. The transmural pressure was changed by introducing different volumes of $\mathrm{K}-\mathrm{H}$ solution into the segment. Means $\pm \mathrm{SEM}, \mathrm{n}=3-4$ animals. (Reproduced with permission of Sparrow et al., 1992.)

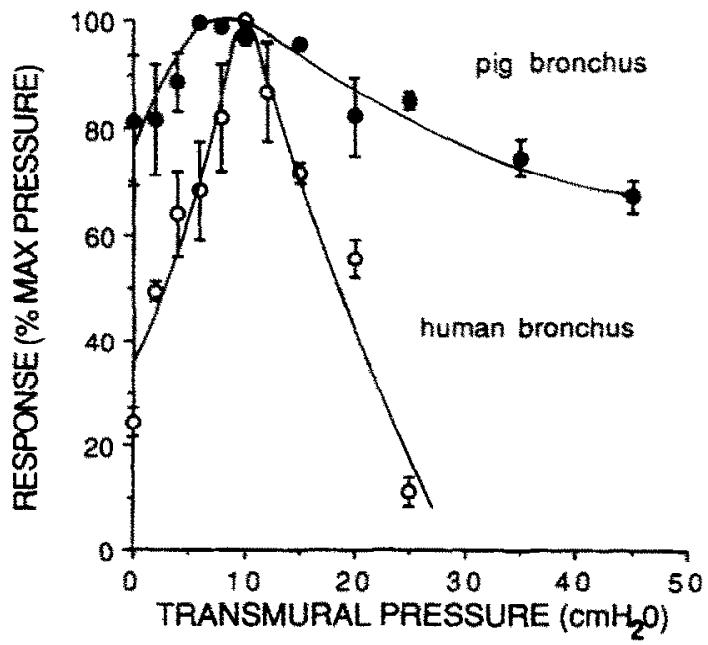

hyperemia and hyperpermeability of bronchial vessels may increase aifflow resistance and airway responsiveness to bronchoconstricting agents (Persson, 1986; Lockhart et al., 1992). These aspects cannot be studied in isolated airways smooth muscle preparations. In isolated whole-lung preparations, however, relationships between airways and the vascular systems are preserved.

Models of dog, rat, rabbit, and guinea pig perfused and ventilated lungs have been described (Evans and Starling, 1934; West et al., 1964; Maloney et al., 1968; Levey and Gast, 1966; Hauge, 1972; Niemeier and Bingham, 1972; Ryfeldt and Nilsson, 1978). After anesthesia, animals are tracheotomized, and a cannula is inserted into their trachea and connected to a ventilator. Then the thorax is opened, and heparin sodium is injected into either the right ventricle or intravenously, The pulmonary artery and pulmonary vein or the left atrium are cannulated, and the blood is flushed from the pulmonary circulation with $\mathrm{K}-\mathrm{H}$ solution at $37^{\circ} \mathrm{C}$. The lungs are either left in situ (Wang et al., 1992) or removed from the thorax and placed in a water vaporsaturated glass or perspex chamber warmed to $37^{\circ} \mathrm{C}$. During the experiment the lungs are perfused via the pulmonary artery with oxygenated $\mathrm{K}-\mathrm{H}$ buffer $\left(37^{\circ} \mathrm{C}\right)$ containing $4 \%-5 \%$ bovine albumin or with whole blood 


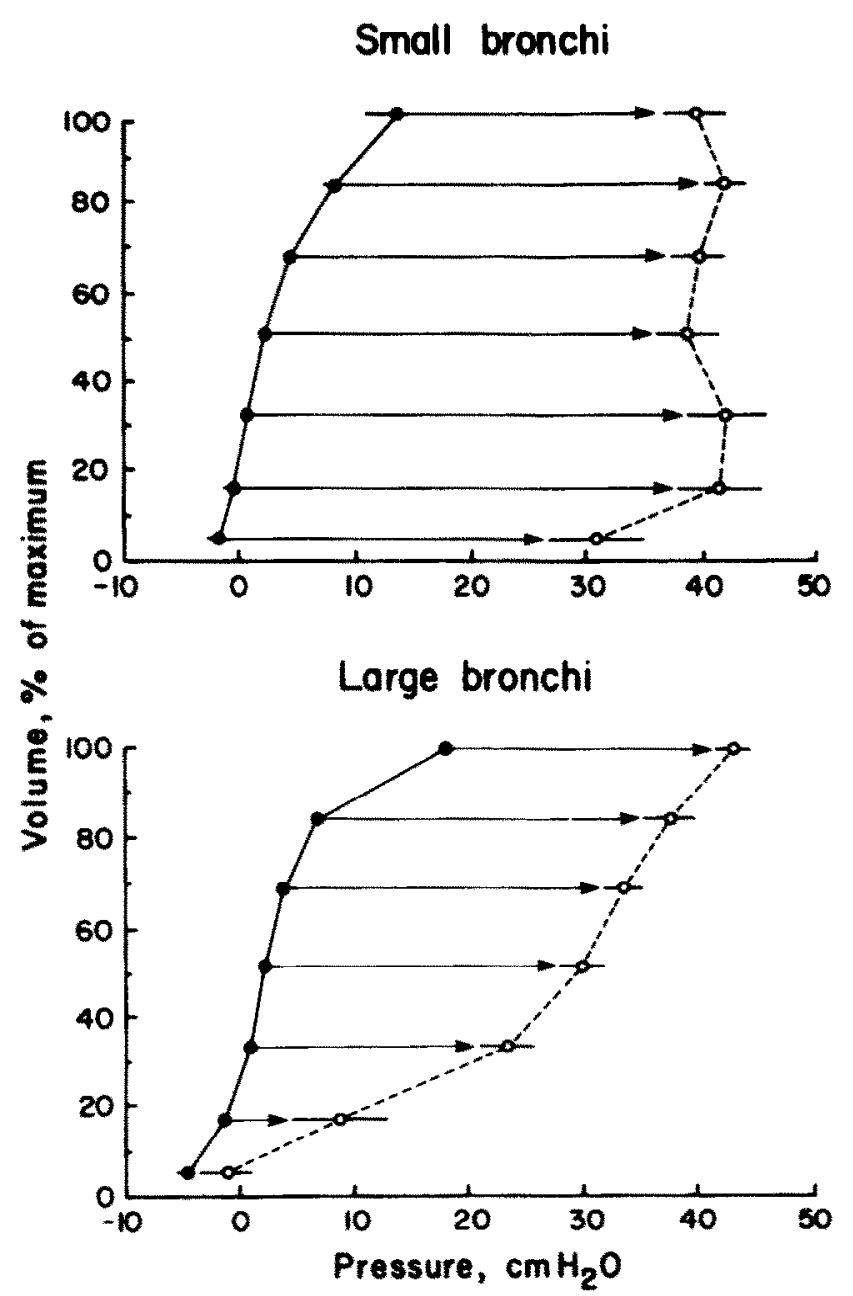

Figure 6. Maximal pressures developed by small $(n=6)$ and large $(n=7)$ bronchi. Closed circles represent passive pressure obtained $1 \mathrm{~min}$ after inflation. Open circles represent pressures obtained after contraction with acetylcholine $\left(10^{-3} \mathrm{M}\right)$. (Reproduced with permission of Gunst et al., 1988.)

under either constant pressure or constant flow conditions. In most studies the preparation is ventilated with preheated and humidified gas by creating a rythmically varying negative pressure $\left(-3\right.$ to $\left.-12 \mathrm{~cm} \mathrm{H}_{2} \mathrm{O}\right)$ in the thorax chamber. Alternatively, positive pressure ventilation has been used (Levey and Gast, 1964; Hauge, 1967; McDonald and Heffner, 1991; Jensen et al., 1992). Weight gain during the experiment, indicating extravasation of the perfusate, is continuously monitored or measured before and after the experiment. In Figure 7 the experimental set-up of an isolated perfused and ventilated guinea pig lung is displayed.

The absence of perfusion of the bronchial circulation and lymphatic drainage are considered as major drawbacks in these preparations. However, after perfusion of the pulmonary artery with fluorescein isothio- cyanate (FITC-D, MW 150,000) Kröll et al. (1987) found abundant presence of FITC-D in tracheobronchial tissue. This indicates functioning anastomoses between the pulmonary and the bronchial circulation, and this increases the validity of this model. In order to ensure oxygenation of medium-sized and large airways, Kroll et al. (1986) ventilated the isolated lung with supranormal $\mathrm{O}_{2}$ tension.

The nonfunctioning lymphatic system, fluid extravasation, and the use of an artificial perfusion medium may lead to a weight gain during perfusion (Fisher et al., 1980; Kröll et al., 1986). Nevertheless, preparations can be used for several hours during which the lung function remains stable (Kröll et al., 1986). The model can be used for the measurement of lung resistance $\left(R_{L}\right)$ and dynamic compliance $\left(C_{D y n}\right.$; Kröll et al., 1986) and for metabolic and pharmacological studies. Furthermore, Wang et al. (1992) showed that it is possible to measure capillary transit time in isolated rabbit lungs by fluorescence video microscopy. No studies in perfused ventilated human lungs have been described, probably because a fresh whole-lung preparation is rarely available.

It might be possible to develop a model for the perfusion and ventilation of human lung lobes or segments. However, the fact that the blood supply of a given ventilatory unit comes from several vascular units (Weibel, 1991) may provide a major problem in preparations of human lung segments.

\section{Preparation and Overnight Storage}

Animal airways tissue can be usually studied immediately after removal. Human airway tissue, however, is often obtained with some delay because pathological examinations have to be performed. In case of autopsy there may be even many hours of delay. In a study by Ferguson and Richardson (1978) lung tissue was obtained at autopsy within $5 \mathrm{hr}$ of death. Electron microscopy of epithelium and smooth muscle cells showed swelling of mitochondria and endoplasmatic reticulum, condensation of cell nuclei and blebs in the cell membrane. In addition, in the smooth muscle cells disorganization and clumping of the contractile filaments was seen (Ferguson and Richardson, 1978). These changes were largely reversible after incubation of the tissue in organ baths containing carbogenated $\mathrm{K}-\mathrm{H}$ buffer solution. Although this may indicate recovery of the preparation from the anoxic period, only brief functional studies were performed by the authors.

Bronchial tissue obtained at thoracotomies seems preferable because the anoxic damage and autolysis can be largely avoided when the tissue is submerged in cooled $\left(0\right.$ to $\left.4^{\circ} \mathrm{C}\right) \mathrm{K}-\mathrm{H}$ buffer solution immediately after surgical resection. de Jongste et al. (1985) de- 


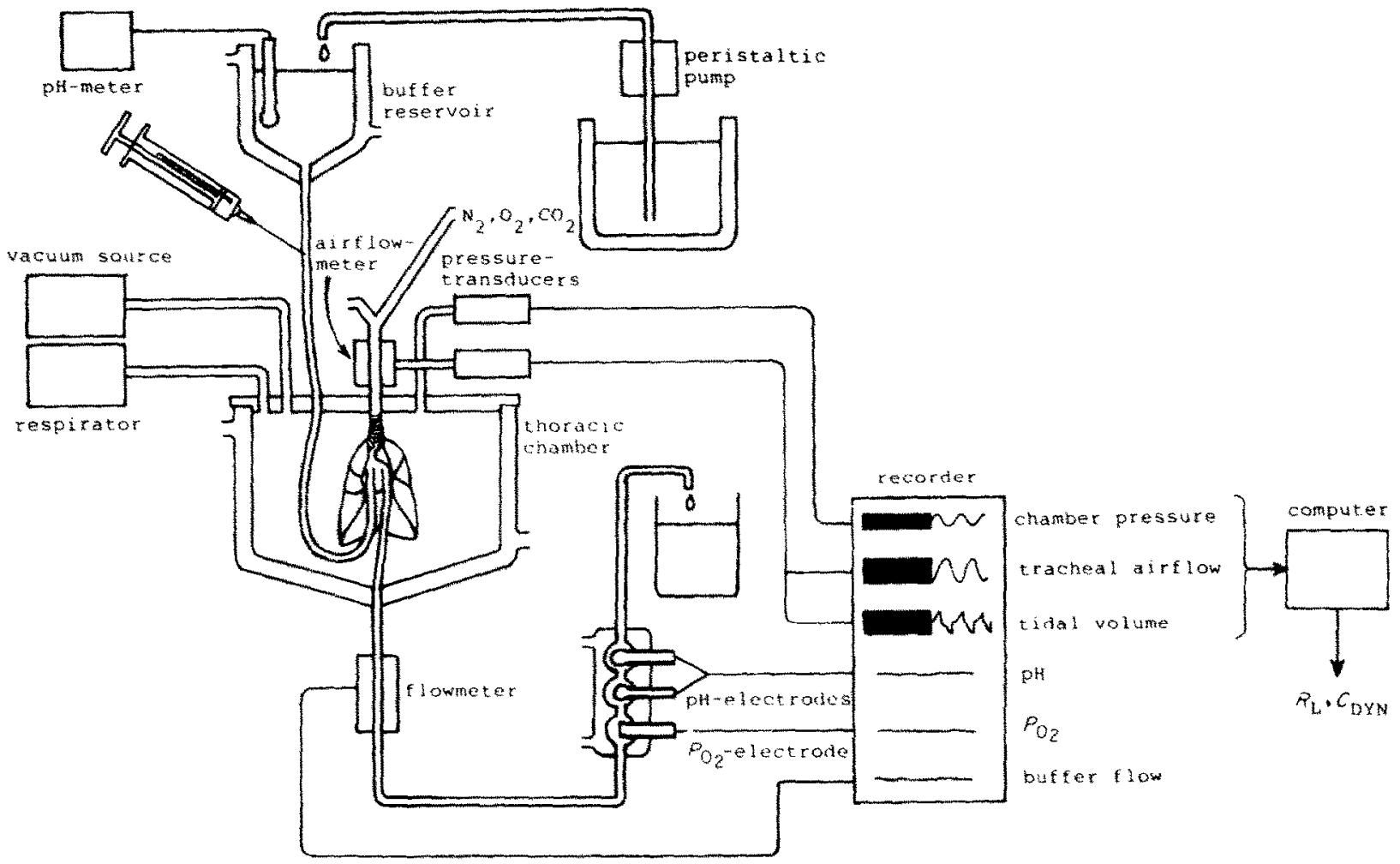

Figure 7. Experimental set-up for studies in isolated perfused lungs. (Reproduced with permission of Kroll et al., 1986.)

scribed a technique for preparation and storage of human lung tissue. After washing to remove blood, bronchi are identified on the cut surface of the excised lung tissue and cannulated with polyethylene tubes. Air is gently inflated to ascertain that an airway, and not a blood vessel, is cannulated. The airway is carefully separated from the surrounding tissue guided by the cannula. Thereafter, blood vessels, lymphatic tissue, and parenchyma are removed from the airway with iris scissors under a binocular preparation microscope (de Jongste et al,, 1985). The airway tubes can be cut into helical or transversal strips or rings.

Tissue preparations can be stored overnight in cooled $\left(4^{\circ} \mathrm{C}\right)$ Ringer's solution (Hawkins and Schild, 1951) or, preferably, cooled, and carbogenated K-H solution (Brink et al., 1980; de Jongste et al., 1985; Raeburn et al., 1986b). With K-H buffer, the response to methacholine remains unchanged until up to $55 \mathrm{hr}$ after resection (de Jongste et al., 1985). To prevent bacterial overgrowth, we note antibiotics, for example, penicillin $\left(3 \times 10^{-5} \mathrm{~g} / \mathrm{L}\right)$ and tobramycin $\left(5 \times 10^{-3}\right.$ g/L) should be added.

\section{Physiological Salt Solutions}

In vitro studies are performed in glass or Plexiglass organ baths filled with a physiological salt solution.
Plexiglass organ baths can be a problem because interaetion of several drugs with synthetics has been described (Krieglstein et al., 1972).

A physiological salt solution is a solution of inorganic salts in which an isolated organ or tissue survives for some time and displays most of its normal functions. The critical ions in any salt solution are sodium, potassium, calcium, and bicarbonate. Sodium and chloride are the main osmotic ions; potassium, calcium, sodium, and magnesium are important for contractility. Bicarbonate is part of a bicarbonate-carbon dioxide buffer system. Ringer (1883) was the first to use a physiological salt solution in his studies on the frog heart. The first salt solution for mammalian tissues was devised for the heart by Locke (1901). He increased the salt concentration of Ringer's solution to increase the osmotic pressure and he added glucose $(0.1 \%)$ to improve the survival time of the heart. Tyrode (1910) added phosphate to improve buffering and magnesium to maintain contractility of the smooth muscle preparation. The disadvantage of Tyrode's solution is its tendency to become alkaline and to precipitate calcium carbonate. In the solution of Krebs and Henseleit (1932), a higher concentration of bicarbonate is used, similar to that found in plasma. The solution should be gassed with carbogen $\left(95 \% \mathrm{O}_{2}, 5 \% \mathrm{CO}_{2}\right)$ to achieve a $\mathrm{pH}$ of 7.4. For studies on tissue respiration, 
Krebs (1950) replaced part of the sodium chloride with sodium salts of fumaric-, pyruvic-, lactic-, or glutaric acid as additional substrates apart from glucose. The $\mathrm{K}-\mathrm{H}$ solution is most widely used. In studies of perfused isolated organs, a colloid should be added to the physiological salt solution in order to prevent edema. Several colloids have been used including dextrans (Grönwall, 1957), polyvinylpyrrolidone (PVP; Ross, 1972) and bovine serum albumin (Schimassek, 1962). Most investigators use albumin, however, disadvantages of albumin are its tendency to lower the $\mathrm{pH}$, to bind calcium ions, and to froth when aerated (Burton, 1975).

Although most physiological salt solutions are gassed with carbogen $\left(95 \% \mathrm{O}_{2}, 5 \% \mathrm{CO}_{2}\right)$, perfused mammalian organs may need more oxygen than can be provided in this way. Oxygen transport can be increased by using erythrocytes or fluorocarbons (Sloviter et al., 1969; Goodman et al., 1973; Hartmann et al., 1984). Fluorocarbons are inert organic substances in which the hydrogen atoms are replaced by fluorine. They have the capacity to carry more oxygen than can be carried in human whole blood (Burton, 1975). In the perfused ventilated lung, however, addition of an oxygen carrier may not be necessary because during ventilation of the preparation with supranormal $\mathrm{O}_{2}$ tension, tissue hypoxia does not seem to be a problem (Kröll et al., 1986).

\section{Recording of Responses}

\section{Isometric, Isotonic and Auxotonic Recording}

Mechanical muscle activity can be measured under isotonic, isometric, and auxotonic conditions. Under isotonic conditions, changes in length are recorded in a muscle to which a constant predetermined load is applied [Figure 8(a)]. Isometric recordings can be made by measuring changes in force of contraction in a muscle preparation which has a constant predetermined length [Figure $8(\mathrm{~b})]$. When changes in length and changes in force are measured simultaneously in a muscle preparation where the applied load increases while the muscle shortens, this is called auxotonic (auxanein $(\mathrm{Gr})=$. to increase) [Figure 8(c)]. In the early days of research of smooth muscle contractility in vitro, isotonic recording techniques were standard: The preparation was connected to the short arm of a lever, the long arm of which recorded changes in muscle length on a slowly moving kymograph. When isometric transducers became available length-tension relationships in canine tracheal smooth muscle were examined (Stephens and Van Niekerk, 1977; Figure 9). The preparations were stepwise stretched, and the resulting passive load and the total contractile force after EFS were
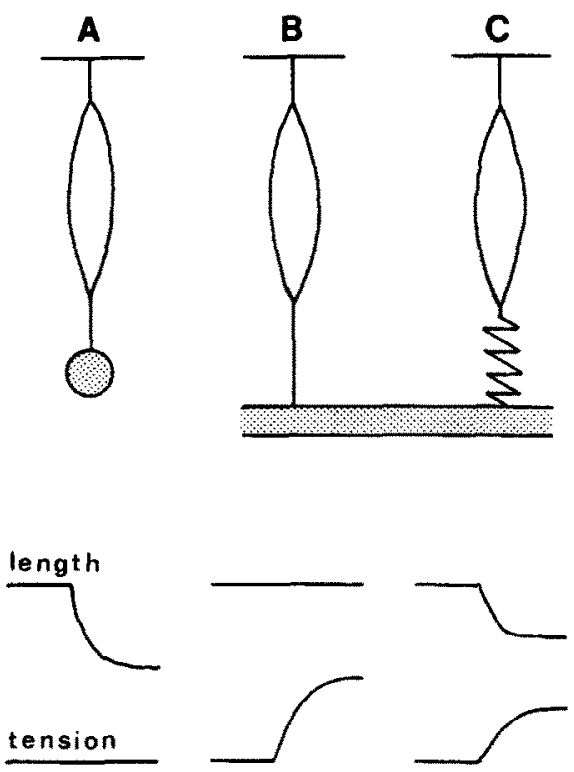

Figure 8. Recording of tension and length changes of smouth muscle obtained under isotonic (A), isometric (B), and auxotonic $(\mathrm{C})$ conditions.

recorded. The active load causing isotonic shortening can be derived by subtraction of resting luad from total force generated. The active force development in airway preparations increases with length until an optimal length $\left(\mathrm{L}_{0}\right.$ or $\left.\mathrm{L}_{\max }\right)$ is reached. The passive tension at $\mathrm{L}_{\max }$ is only $5 \%$ to $10 \%$ of the active tension. The horizontal difference between the active and the total tension (arrows in Figure 9) represents the smooth muscle shortening under isotonic conditions. When the muscle is stretched beyond $\mathrm{L}_{\max }$, the maximum, active

Figure 9. Length-tension relationships of airway smooth muscle. The active tension curve is obtained by subtracting passive tension from total tension. The isometric curve is also shown. The arrows indicate isotonic smooth muscle shortening at different lengths. (Modified from Stephens and Van Niekerk, 1977.)

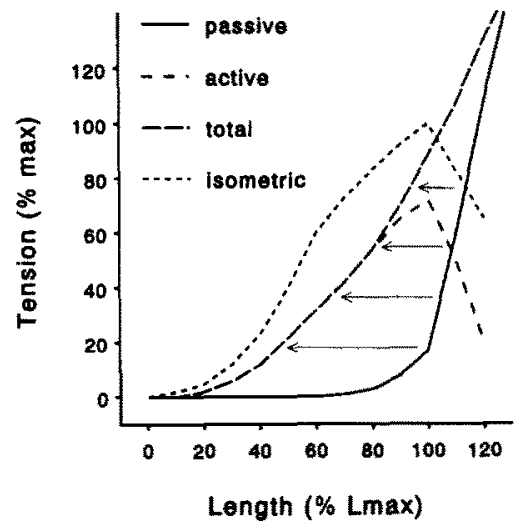


tension will decrease. At all muscle lengths, force development in isometric experiments is higher, indicating that in isotonic contraction the smooth muscle does not contract fully (Stephens and Van Niekerk, 1977). This incomplete contraction may be due to thickening of the muscle-hindering diffusion of the neurotransmitter and folding of contractile elements impairing optimal functioning (Michelson and Shelkovnikov, 1976; Stephens and Van Niekerk, 1977). At function residual capacity (FRC) in vivo, the tracheal smooth muscle may be stretched to around $\mathrm{L}_{\max }$ (Moreno et al., 1986). The experiments of Stephens and Van Niekerk (1977) imply that, for optimal results, isolated airway preparations should be stretched to approximately $\mathrm{L}_{\max }$ by either applying a weight (isotonic measurements) or increasing baseline length (isometric measurements).

In the rabbit bronchus, Armour et al. (1988) found a correlation between the maximal isometric force generation in response to carbachol and the amount of airway smooth muscle present in the airway preparation. In contrast, the maximal isotonic shortening was not related to the smooth muscle content of the preparation, and it was concluded that isometric measurements are preferable because they represent changes in smooth muscle contraction in response to an agonist more accurate (Armour et al., 1988).

In human small airways, however, only small differences were found between both methods, perhaps bccause the experiments were performed under near optimal tension and length conditions (de Jongste et al., 1987d). Although both recording techniques allow accurate and reproducible measurements of force generation, airway smooth muscle contraction in vivo is neither isometric nor isotonic, but auxotonic: during narrowing the load against which the smooth muscle shortens increases due to an elastic load provided by the surrounding structures (Moreno et al., 1986; Sparrow et al., 1992). This situation has been simulated in a study performed by Ishida et al. (1990) who measured the effect of elastic loads on smooth muscle shortening in pig isolated airways. It was shown that, at small loads, contractile responses were more or less isotonic, whereas, at large loads, minimal shortening was found indicating a isometric response (Ishida et al., 1990). Thus the size of the elastic load on the airway provided by the airway wall and the surrounding tissue determines the degree to which a contraction is isometric or isotonic.

\section{Pressure or Flow Recording}

The responses of perfused airway tube preparations are measured by recording changes in flow rate or perfusion pressure, depending on whether experiments are done under constant pressure or constant flow con- ditions, respectively. The configuration of the airway is left intact and the mode of contraction is more physiological than that in an airway strip preparation. However, in the constant flow model, the transmural pressure increases during contraction and this will influence the load on the muscle in an elastic (auxotonic) way. In the constant pressure model, airway closure may occur at higher doses of a contracting agonist (Mitchell et al., 1989), and this precludes accurate determination of the pharmacological sensitivity $\left(\mathrm{EC}_{50}\right)$ of the preparation.

In human peripheral airways perfused at a constant pressure, we were able to avoid airway closure by stretching the airway preparations to $140 \%$ of their initial length (Hulsmann et al., 1992).

\section{Other Methods to Record Airway Responses}

Other techniques to record airway responses have been developed and are briefly described below. These methods, however, are not commonly used, and their value remains to be established.

High-resolution ultrasonic imaging. In order to visualize airways smooth muscle contraction in vitro, lizuka et al. (1992) introduced an ultrasonic catheter in porcine and human isolated bronchi. The ultrasound technique produced a three-layer image of the bronchial wall corresponding to the mucosa, cartilage, and adventitia. The muscle could not be distinguished from the mucosa. Dose-dependent responses to acetylcholine could be obtained, and it was found that human bronchus contracts elliptically, not circularly (Iizuka et al., 1992). Because the diameter of the transducer is $1.7 \mathrm{~mm}$, the technique can be only used in airways of at least this size.

Sonomicrometry. Okazawa et al. (1990) measured length changes of canine trachealis muscles in vivo with sonomicrometry. This technique uses the transit time of ultrasound traveling between two piezoelectric crystals as a measure for the linear distance between these crystals. Small $(1 \mathrm{~mm})$ piezoelectric transducers were placed in the posterior tracheal wall in parallel with the muscle fibers. Length changes during mechanical ventilation and pressure-volume curves could be obtained. This method may be applicable in isolated large airways as well.

High-resolution computed tomography. With this technique, airways of 1-2 mm diameter can be visualized (Todo et al., 1986), and this method has been used to study carbachol-induced changes in airway dimensions in excised canine lung lobes (McNamara et al., 1992). The degree of airway narrowing could be accurately quantified, and it was shown that airway narrowing after carbachol is greatest in intermediate-sized airways (internal diameter: 2-6 mm). 
Photoelectric recording. Schabert et al. (1980) developed a photoelectric method to record changes in blood vessel diameter. A beam of parallel infrared light is directed at right angles to the blood vessel. The light passing the side of the vessel is a measure of the outer vessel diameter and is detected by a photocell. A decrease in vessel diameter causes an increase in photocell current. In isolated airways, photoelectric methods have been only used to study respiratory ciliary activity (Yager et al., 1980; Tamaoki et al., 1989).

\section{Between-patient and Within-patient Variability}

With the above-mentioned recording techniques, accurate and reproducible measurement of parameters such as tissue sensitivity $\left(\mathrm{EC}_{50}\right)$, maximal contraction, or relaxation and intrinsic (baseline) tone is possible in human airway strips, rings, and tubes (de Jongste et al., 1985; Jongejan et al., 1988; Hulsmann et al., 1992). However, for some purposes an in vitro model should be able to detect between-patient differences. de Jongste et al. (1985) showed that, despite large within-patient variability, significant between-patient differences in airway strips could be shown for $\mathrm{EC}_{50}$ and maximal response. In airway tubes, between-patient differences in $\mathrm{EC}_{50}$ and intrinsic tone accounted for more than $90 \%$ of the total variability (Hulsmann et al., 1992).

The finding of smaller within-patients variability in airway tubes compared to airway strips may indicate that within-patient variability in airway strips are largely due to disturbance of the airway structure during the cutting of the strips.

\section{Intrinsic Tone}

Isolated airway preparations may exhibit an intrinsic muscle tone. In guinea pig airways, this tone appears to be dependent on prostanoids and not on intrinsic innervation (Orehek et al., 1975). In human airways, however, the role of prostanoids is unclear since both enhancement (Ito et al., 1985) and reduction (Ito et al., 1989) of intrinsic tone have been described after inhibition of cyclooxygenase. In addition, peptidoleukotrienes may be involved because inhibition of 5-lipoxygenase decreased intrinsic tone (Ito et al., 1989). Mansour and Daniel (1986) expressed the responses of guinea pig tracheas on a scale between maximal relaxation and maximal tension in response to carbachol. It appeared that the responses to exogenous arachidonate were dependent on the intrinsic tone of the airway preparation. When this intrinsic tone was low, contraction was found; when it was high, relaxa- tion was found. Their findings emphasize the importance of the expression of responses on a scale that displays the maximal active contractile range (MACR) in order to be able to compare responses of different airway preparations. Monitoring intrinsic tone is also relevant when EFS is used. With high intrinsic tone, EFS may predominantly give relaxations, whereas with low tone, contraction will result.

We routinely determine maximal contraction to exogenous cholinergic stimulation at the beginning of experiments, and maximal relaxation to $\beta$-adrenoceptor stimulation and calcium free buffer after completion of the experiments. Alternatively, a supramaximal dose of theophylline, sodium nitroprusside, or papaverine can be used to obtain maximal relaxation.

\section{Removal of the Epithelium}

Classically, the modulatory role of the airway epithelium is evaluated in paired observations of intact and epithelium-denuded isolated airway preparations. The epithelium is commonly removed by "gentle rubbing" with a wet gauze, and its effectiveness is verified histologically (Flavahan et al., 1985; Aizawa et al., 1988; Jongejan et al., 1991).

In guinea pig tracheas the effectiveness of epithelium removal can be also verified functionally by adding arachidonic acid which causes smooth muscle contraction in epithelium-denuded tracheas, whereas intact tracheas respond with relaxation (Nijkamp and Folkerts, 1987). This procedure has not been tested in human airways.

With mechanical rubbing, it is possible to remove over $95 \%$ of the epithelium leaving the basal membrane and the smooth muscle histologically intact. However, Franconi et al. (1990) showed that mechanical rubbing of the epithelium may lead to release of granules containing tryptase from mast cells present in the lamina propria.

In dog airways, tryptase causes hyperresponsiveness, probably due to an effect on $\mathrm{Ca}^{2+}$-channels (Sekizawa et al., 1989). This mechanism may explain at least part of the hyperresponsiveness reported in epithelium-denuded airways. Furthermore, epithelial damage and denudation in asthma is not caused by mechanical rubbing but, probably, by the release of the basic proteins such major basic protein (MBP) and eosinophil peroxidase (EPO) and oxygen radicals released from inflammatory cells present in the inflamed airway (Frigas and Gleich, 1986; Barnes, 1989; Montefort et al., 1992). Deposits of EPO were found in areas of mucosal injury in asthmatics (Bousquet et al., 1992). Human MBP causes epithelial damage (Motojima et al., 1989) and hyperresponsiveness in vitro (Flavahan et al., 1988) and in vivo (Gundel et al., 1991). 
Oxygen radicals increase the permeability of cultured epithelium (Welsh et al., 1985) as well as epithelium in the guinea pig trachea (Jeppsson et al., 1989), and the responsiveness of human airways is enhanced after damaging the epithelium with hydrogen peroxide (Hulsmann et al., 1993a). In a model of asthma it may be more appropriate to use these aggressive substances rather than mechanical rubbing to induce epithelial damage.

Apart from basic proteins and oxygen radicals, several other methods for damaging and removal of epithelium in vitro have been described.

Franconi et al. (1990) removed epithelium from animal and human airways by perfusing the preparations during $0.5-2 \mathrm{hr}$ with pronase (protease type XIV; 1 $\mathrm{mg} / \mathrm{mL}$ ). Where the epithelium was effectively removed, the integrity of mast cells in the lamina propria and the smooth muscle was not affected.

Interferon- $\gamma$, produced by intraepithelial $\mathrm{T}-\mathrm{lym}$ phocytes (Ebert, 1990) enhances tight junction permeability in a human intestinal epithelial cell line (Madara and Stafford, 1989) but has not been examined in airway epithelium.

Perfusion of rat arteries with a hypotonic Tyrode solution (Pelissier et al., 1992) or the nonionic, nondenaturing detergent CHAPS (3-[(3-cholamidopropyl)-dimethyl-ammonio]-1-propanesulfonate; Tesfamariam et al., 1985; Yang et al., 1989) resulted in a disruption of endothelial cells, and this method may be applicable for endothelial cell removal in airways as well. It appears, therefore, that there are alternatives for the mechanical removal of airway endothelium. These alternatives have the advantage that they may mimic the damage that is found in asthma (basic proteins and oxygen radicals) or that they produce less artifacts (pronase).

\section{Electrical Stimulation}

Basically, there are two methods of electrical stimulation of isolated organ preparations: contact stimulation using electrodes that are attached to the tissue and field stimulation via electrodes that are not in direct contact with the tissue. Also, one electrode may be in contact with the tissue, while the other, often a ring, is not (hybrid stimulation). Electric field stimulation is most commonly used to study neural responses in smooth muscle preparations including isolated airways. The technique is relatively simple platinum- or silver-silver chloride sheet electrodes are suspended close to, but not in contact with, the tissue, in an organ bath containing K-H solution (Figure 2). A stimulator generates rectangular pulses of short duration $(0.1-1$ msec) at a constant current. Voltage- and frequencyresponse curves can be obtained and the interval between stimuli and pulse width can be varied (Figure $10)$.

EFS was introduced by Paton in 1955 who demonstrated that single electrical pulses $(1-25 \mathrm{~V}, 0.5 \mathrm{msec})$ elicited brief twitches $(1 \mathrm{sec})$ in the guinea pig isolated ileum (Paton, 1955). Since the twitch was abolished by

Figure 10. Effect of change in pulse-voltage, -frequency, and -width on the contraction and relaxation responses of human bronchial strips. (A) Effect of voltage $(0-50 \mathrm{~V})$ with constant frequency $(30 \mathrm{~Hz})$ and pulse width $(0.3 \mathrm{msec})$. (B) Effect of frequency $(0-50 \mathrm{~Hz})$ with constant voltage $(30 \mathrm{~V})$ and pulse width $(0.3 \mathrm{msec})$. (C) Effect of pulse width $(0.2-0.75 \mathrm{msec})$ with constant voltage $(30 \mathrm{~V})$ and frequency $(30 \mathrm{~Hz})$. Pulse trains of $30 \mathrm{sec}$. Contractions and relaxations are expressed as a percentage of the maximal response in a given strip. Mean values \pm SEM of four to five experiments are shown. (Reproduced with permission of de Jongste et al., 1987e.)

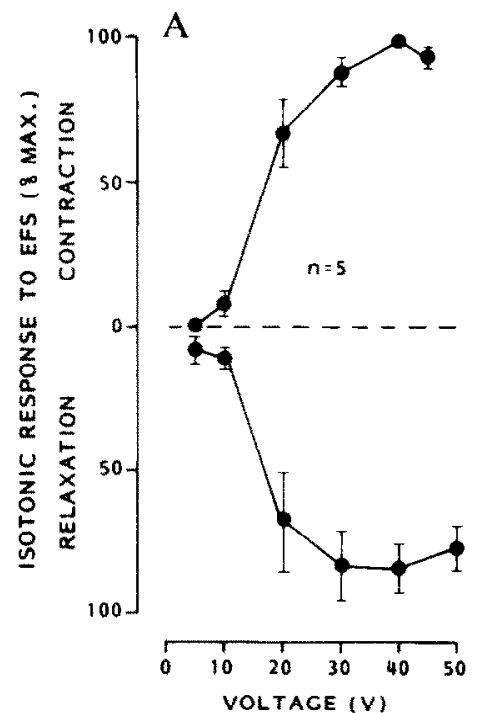

VOLTACE (V)
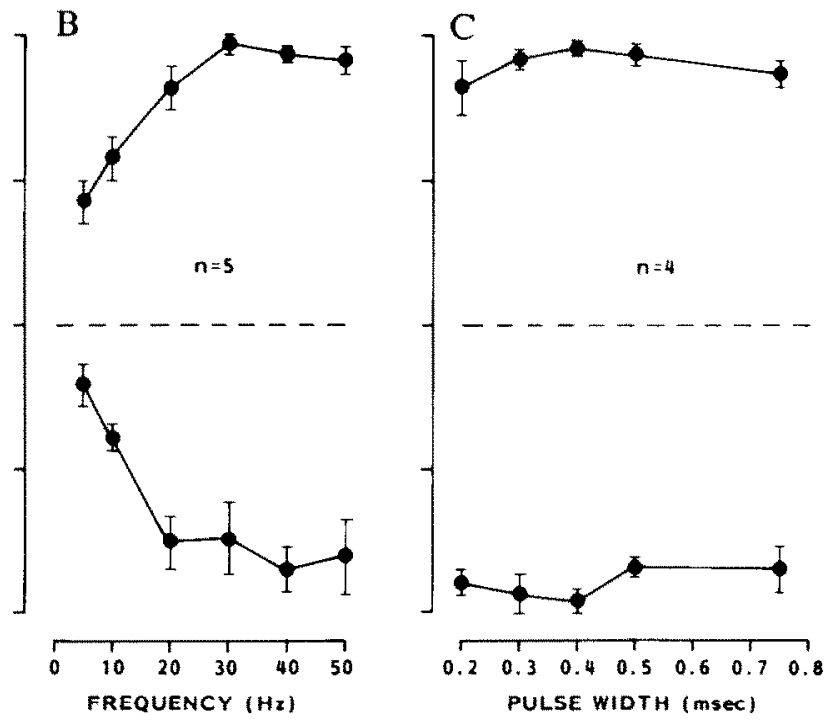
atropine, prolonged by eserine, and was insensitive to hexamethonium, he concluded that postganglionic nerve fibers were excited by EFS. In later studies it was confirmed that with appropriate stimulation parameters, nerve fibers can be activated selectively without stimulating the smooth muscle directly (Paterson, 1965; Duckles and Silverman, 1980). In human airways, EFS causes a fast, nerve-mediated cholinergic contraction followed by a slow nonadrenergic, noncholinergic inhibitory nerve-mediated (i-NANC) relaxation (Richardson and Béland, 1976; Davis et al., 1982; Taylor et al., 1984; de Jongste et al., 1987c). In addition, de Jongste et al. (1987c) found a rapid nonneural contraction and a sustained nonneural contraction resulting from synthesis of cyclo-oxygenase metabolites and leukotriene-like substances by fresh human airway tissue, respectively (Figure 11). These nonneural contractions may interfere with neural responses and should be taken into account as a confounding factor. In guinea pig airways vasoactive intestinal peptide (VIP) and nitric oxide (NO) may be the neurotransmitters of the nonadrenergic inhibitory nerves ( $\mathrm{Li}$ and Rand, 1991; Lei et al., 1993), whereas in human bronchi the response may be due mainly to NO (Belvisi et al., 1992b; Ellis and Undem, 1992).

Although EFS is a useful tool to evoke neural responses in isolated airway tissues, the technique has an important side effect. During EFS with commonly

Figure 11. Schematic representation of time course, peak latency, and amplitudes of the four phases that constitute the response of fresh human bronchus to electrical field stimulation (EFS) in vitro. Phases are numbered according to peak latency after EFS: 1, cholinergic nerve-mediated, rapid contraction; 3 , nonadrenergic inhibitory nerve-mediated relaxation; 2 and 4 , nonneural contraction due to the release of cyclooxygenase and lipoxygenase metabolites, respectively. (Reproduced with permission of de Jongste et al., 1987c.)

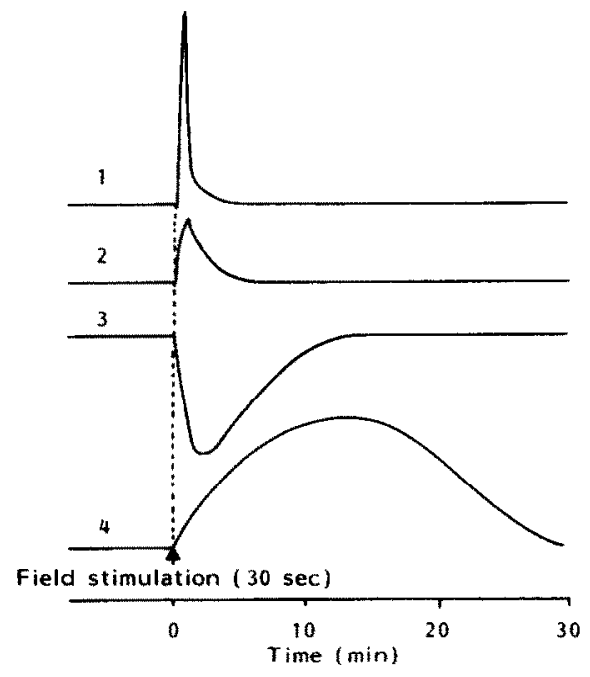

used stimulation parameters activated oxygen molecules may be generated in carbogenated K-H buffer. These activated oxygen molecules have been shown to relax smooth muscle preparations directly (Greenberg et al., 1986) and may oxidize contractile drugs (Wyse, 1977; Hulsmann et al., 1993b). The inactivation of histamine by EFS may even occur at a frequency of $2 \mathrm{~Hz}(50 \mathrm{~V}$, pulse duration $0.3 \mathrm{~ms}$; Hulsmann et al., 1993b).

\section{Conclusions and Directions for Future Research}

In the present overview, we discussed models that have been developed over the years to study the effects of drugs, inflammatory mediators, autonomic nerves, and epithelial cells on the responsiveness of airway smooth muscle in vitro. These models range from the simple bronchial strip preparation to the complex ventilated and perfused lung preparation. Although these models have substantially contributed to the progress in our understanding of the pathophysiology of asthma and COPD, the precise relationships between airway inflammation, bronchial hyperresponsiveness, and airway narrowing is still not clear. The relative contributions of inflammatory cells and their products, of autonomic nerves and of the tracheo-bronchial circulation to airway disease should be further investigated. With the currently available in vitro models, however, the role of the bronchial circulation in airway disease cannot be elucidated. Efforts should now be made to develop models in which the normal relationships between the ventilatory and the circulatory unit is preserved in vitro. The study of isolated perfused and ventilated lung tissue may be an important step in this direction, and it might be possible to develop such a model for the human lung.

A.R.H. is supported by grant 90.43 from the Dutch Asthma Foundation.

\section{References}

Advenier C, Freston J-L (1985) The guinea pig isolated bronchus for the in vitro study of small calibre airway reactivity, $\mathrm{Br} J$ Pharmacol 86:367-373.

Advenier C, Devellier P, Matran R, Naline E (1988) Influence of epithelium on the responsiveness of guinea pig isolated trachea to adenosine. Br J Pharmacol 93:295-302.

Aizawa H, Miyazaki N, Shigematsu N, Tomooka M (1988) A possible role of airway epithelium in modulating hyperresponsiveness. Br J Pharmacol 93:139-145.

Armour CL, Diment LM, Black JL (1988) Relationship between smooth muscle volume and contractile response in airway tissue: Isometric versus isotonic measurement. J Pharmacol Exp Ther 245:687-691. 
Bahous J, Cartier A, Ouimet G, Pineau L, Malo JL (1985) Nonallergic bronchial hyperexcitability in chronic bronchitis. Am Rev Respir Dis 129:216-220.

Bai TR (1990) Abnormalities in airway smooth muscle in fatal asthma. Am Rev Respir Dis 141:552-557.

Barnes PJ (1989) New concepts in the pathogenesis of bronchial hyperresponsiveness and asthma. J Allergy Clin Immunol 83: 1013-1026.

Belvisi MG, Miura M, Peters MJ, Ward JK, Tadjkarimi S, Yacoub MH, Giembycz \&, Barnes PJ (1992a) Effect of isoenzyme-selective cyclic nucleotide phosphodiesterase inhibitors on human tracheal smooth muscle tone. Br J Pharmacol 107:53P.

Belvisi MG, Stretton CD, Yacoub M, Barnes PJ (1992b) Nitric oxide is the endogenous neurotransmitter of bronchodilator nerves in humans. Eur J Pharmacol 210:221-222.

Bertram JF, Goldie RG, Papadimitriou JM, Paterson JW (1983) Correlation between pharmacological responses and the structure of human lung parenchyma strips. Br J Pharmacol 80:107:114.

Bousquet J, Chancz P, Lacoste JY, Barnćon G, Ghavanian N, Enander I, Venge P, Ahlstedt S, Simony-Lafontaine J, Godard P, Michel F-B (1990) Eosinophilic inflammation in asthma. $N$ Engl J Med 323:1033-1039.

Brink C, Grimaud C, Guillot C, Orehek J (1980) The interaction between indomethacin and contractile agents on human isolated airway muscle. Br J Pharmacol 69:383-388.

Burton RF (1975) Ringer Solutions and Physiological Salines. Bristol: John Wright \& Sons Ltd.

Castillo JC, De Beer EJ (1947) The tracheal chain: A preparation for the study of antispasmodics with particular reference to bronchodilator drugs. J Pharmacol 90:104-109.

Cerrina J, Le Roy Ladurie M, Labat C, Raffestin B, Bayol A, Brink C (1986) Comparison of human bronchial muscle responses to histamine in vivo with histamine and isoproterenol agonists in vitro. Am Rev Respir Dis 134:57-61.

Chand N, Deroth L, Eyre P (1979) Pharmacology of Schultz-Dale reaction in canine lung strip in vitro: Possible model for allergic asthma. Br J Pharmacol 66:511-516.

Cockcroft DW (1988) Nonallergic airway responsiveness. $J$ Allergy Clin Immunol 79:734-740.

Constantine JW (1965) The spirally cut tracheal strip preparation. $J$ $J$ Pharm Pharmacol 17:384-385.

Cortijo I, Sarriá B, Pedrós C, Perpiñá M, Paris F, Morcillo E (1992) The relaxant effects of cromokalim (BRL 34915) on human isolated airway smooth muscle. N-S Arch Pharmacol 346:462-468.

Cosio MG, Hale KA, Niewoehner DE (1980) Morphologic and morphometric effects of prolonged cigarette smoking on the small airways. Am Rev Respir Dis 122:265-271.

Davis C. Kannan S, Jones TR. Daniel EE (1982) Control of human airway smooth muscle: In vitro studies. J Appl Physiol 53: $1080-1087$

de Jongste JC, Van Strik R, Bonta IL, Kerrebijn KF (1985) Measurement of humna small airway smooth muscle function in vitro with the bronchiolar strip preparation. J Pharmacol Meth 14:111-118.

de Jongste JC, Sterk PJ, Mons H, Timmers M, Kerrebijn KF (1987a) Comparison of maximal airway narrowing in vivo and small airway smooth muscle contractility in vitro in non-asthmatic humans. Am Rev Respir Dis 138:321-326.

de Jongste JC, Mons H, Bonta IL, Kerrebijn KF (1987b) In vitro responses of airways from an asthmatic patient. Eur J Respir Dis 71:23-29.

de Jongste JC, Mons H, Bonta IL, Kerrebijn KF (1987c) Nonneural components in the response of fresh human airways to electrical field stimulation. $J$ Appl Physiol 63:1558-1566.

de Jongste JC, Mons H, Van Strik R, Bonta IL, Kerrebijn KF (1987d) Comparison of isometric and isotonic response of human small airway smooth muscle in vitro. $J$ Pharmacol Meth 17:165-171. de Jongste (1987e) Human Airway Smooth Muscle. Erasmus University, Rotterdam, The Netherlands: Thesis.

de Jongste JC, Kerrebijn KF (1988) Is bronchial hyperresponsiveness in humans a smooth muscle abnormality? In Mechanisms in Asthma: Pharmacology, Physiology, and Management. Eds., CL Armour and JL Black. New York: Alan R. Liss. Inc., pp 255-265.

Deffebach ME, Charan NB, Lakshminarayan S, Butler J (1987) The bronchial circulation: Small, but a vital attribute of the lung. Am Rev Respir Dis 135:463-481.

Deffebach ME, Widdicombe J (1991) The bronchial circulation. In The Lung: Scientific Foundations. Eds., RG Crystal and JB West. New York: Raven Press, Ltd., pp 741-755.

Devillier P. Advenier C, Drapeau G, Marsac J, Regoli D (1988) Comparison of the effect of epithelium removal and of enkephalinase inhibitor on the neurokinin-induced contractions of guinea pig isolated trachea. Br J Pharmacol 94:675-684.

Djukanovic R, Roche WR, Wilson JW, Beasley CRW, Twentyman OP, Howarth PH, Holgate ST (1990) Mucosal inflammation in asthma. Am Rev Respir Dis 142:434-457.

Drazen JM, Schneider MW (1978) Comparative responses of trachea spirals and parenchymal strips to histamine and carbachol in vitro. J Clin Invest 61:1441-1447.

Duckles SP, Silverman RW (1980) Transmural nerve stimulation of blood vessel in vitro: A critical examination. Blood Vessels 17: $53-57$.

Ebert EC (1990) Intra-epithelial lymphocytes: Interferon- $\gamma$ production and suppressor/cytotoxic activities. Clin Exp Immunol 82: $81-85$.

Ellis JL, Undem BJ (1992) Inhibition by $\mathrm{L}-\mathrm{N}^{\mathrm{G}}$-nitro-L-arginine of nonadrenergic, noncholinergic-mediated relaxations of human isolated central and peripheral airways. Am Rev Respir Dis 146: $1543-1547$.

Evans CL, Starling EH (1934) The part played by the lungs in the oxidative processes of the body. J Physiol (London) 46:413-434.

Eyre P, Mirbahar KB (1981) Is the lung parenchyma strip a true airway preparation? Agents Actions 11:173-176.

Farmer SG, Hay DWP (1991) Airway epithelial modulation of smooth muscle function: The evidence for epithelium-derived inhibitory factor. In The Airway Epithelium: Physiology, Pathophysiology, and Pharmacology. Eds., SG Farmer and DWP Hay. New York: Marcel Dekker Inc., pp. 437-485.

Fedan JS, Frazer DG (1992) Influence of epithelium on the reactivity of guinea pig isolated, perfused trachea to bronchoactive drugs. $J$ Pharmacol Exp Ther 262:741-750.

Ferguson CC, Richardson JB (1978) A simple technique for the utilization of postmortem tracheal and bronchial tissues for ultrastructural studies. Hum Pathol 9:463-470.

Finney MJB, Berend N, Black JL (1984) Cholinergic responses in the human lung parenchymal strip: A structure-function correlation. Eur J Respir Dis 65:447-455.

Finney MJB ,Karlsson J-A, Persson CGA (1985) Effects of bronchoconstrictors and bronchodilators on a novel human small airway preparation. Br $J$ Pharmacol 85:29-36.

Fisher AB, Dodia C, Linask J (1980) Perfusate composition and edema formation in isolated rat lungs. Exp Lung Res 1:13-21.

Flavahan NA, Aarhus LL, Rimele TJ, Vanhoutte PM (1985) Respiratory epithelium inhibits bronchial smooth muscle tone. $J$ Appl Physiol 58:834-838.

Flavahan NA, Slifman NR, Gleich GJ, Vanhoutte PM (1988) Human eosinophil major basic protein causes hyperreactivity of respiratory smooth muscle. Am Rev Respir Dis 138:685-688.

Franconi GM, Rubinstein I, Levine EH, Ikeda S, Nadel JA (1990) Mechanical removal of airway epithelium disrupts mast cells and releases granules. Am J Physiol 259:L372-L377. 
Frigas E. Gleich GJ (1986) The eosinophil and the pathophysiology of asthma. I Allergy Clin Immunol 77:527-538.

Ghelani AM, Holroyde MC, Sheard P (1980) Response of human isolated bronchial and lung parenchymal strips to SRS-A and other mediators of asthmatic bronchospasm. BrJ Pharmacol 71 : $107-112$.

Goldie RG, Paterson JW, Wale JL (1982) Pharmacological responses of human and porcine lung parenchyma, bronchus and pulmonary artery. Br J Pharmacol 76:515-521.

Goldie RG, Bertram JF, Papadimitriou JM, Paterson JW (1984) The lung parenchyma strip. Trends Pharmacol $S$ ci 5:7-10.

Goldie RG, Spina D, Henry PJ, Lulich KM, Paterson JW (1986) In vitro responsiveness of human asthmatic bronchus to carbachol, histamine, $\beta$-adrenoceptor agonist and theophylline. $\mathrm{Br} I \mathrm{Phar}$ macol 22:669-676.

Goodman MN, Parrilla R, Toews CJ (1973) Influence of fluorocarbon emulsions on hepatic metabolism in perfused rat liver. $A m J$ Physiol 225:1384-1388.

Greenberg B, Rhoden K, Barnes PJ (1986) Activated oxygen molecules generated by electrical stimulation affect vascular smooth muscle. $J$ Mol Cell Cardiol 18:975-981.

Grönwall A (1957) Dextran and Its Use in Colloidal Infusion Solutions. Stockholm: Almquist \& Wicksell.

Gundel RH, Letts LG, Gleich GJ (1991) Human eosinophil major basic protein induces airway constriction and airway hyperresponsiveness in primates. I Clin Invest 87:1470-1473.

Gunst S, Stropp JQ (1988) Pressure-volume and length-stress relationships in canine bronchi in vitro. J Appl Physiol 64:2522-2531.

Hartmann F, Vieillard-Baron D, Heinrich R (1984) Isolated perfusion of the small intestine using perfluorotributylamine as artificial oxygen carrier. Adv Exp Med Biol 180:711-720.

Hauge A (1968) Conditions governing the pressor response to ventilation hypoxia in isolated perfused rat lungs. Acta Physiol Scand $72: 33-44$.

Hawkins DF, Schild HO (1951) The action of drugs on isolated human bronchial chains. Bf J Pharmacol 6:682-690.

Hayes JP, Daniel R, Tee RD. Barnes PJ, Newman Taylor AJ, Chung KF (1992) Bronchial hyperreactivity after inhalation of trimellitic anhydride dust in guinea pigs after intradermal sensitization to the free hapten. Am Rev Respir Dis 146:1311-1314.

Hirshman CA (1985) The Basenji-Greyhound dog model of asthma. Chest 87:172S-178S.

Hooker CS, Calkins PJ, Fleisch JH (1977) On the measurement of vascular and respiratory smooth muscle responses in vitro. Blood Vessels 14:1-11.

Hulsmann AR, Raatgeep HC, Bonta IL, Stijnen T, Kerrebijn KF, de Jongste JC (1992) The perfused bronchiolar tube: Characteristics of a new model. I Pharmacol Toxicol Meth 28:29-34.

Hulsmann AR, Raatgeep HR, Den Hollander JC, Stijnen T, Saxena PR, Kerrebijn KF, de Jongste JC (1993a) Oxidative epithelial damage produces hyperresponsiveness of human periperal airways. Am Rev Respir Dis (in press).

Hulsmann AR, Raatgeep HR, Garrelds IM, Toorenenbergen AWM, de Jongste JC (1993c) Histamine oxidation causes TTX-insensitive relaxation of histamine-precontracted human bronchus to electric field stimulation in vitro. I Pharmacol Toxicol Meth (in press).

lizuka K, Dobashi K, Houjou S, Sakai H, Itoh K, Nakazawa T (1992) Evaluation of airway smooth muscle contractions in vitro by high-frequency ultrasonic imaging. Chest 102:1251-1257.

Ishida K, Paré PD, Hards J, Schellenberg RR (1990) Mechanical properties of human bronchial smooth muscle in vitro. $J$ Appl Physial 73:1481-1485.

Ito M, Baba K, Takagi K, Satake T, Tomita T (1985) Some properties of calcium-induced contraction in the isolated human and guinea pig tracheal smooth muscle. Respir Physiol 59:143-153.
Ito $Y$, Suzuki $H$, Aizawa $H$, Hakoda $H$, Hirose $T(1989)$ The spontaneous electrical and mechanical activity of human bronchial smooth muscle: Its modulation by drugs. Br J Pharmacol 98 : 1249-1260.

Jensen KS, Micco AJ, Czartolomna J, Latham L, Voelkel NF (1992) Rapid onset of hypoxic vasoconstriction in isolated lungs. $J$ App Physiol 72:2018-2023.

Jeppsson A-B, Roos C, Waldeck B, Widmark E (1989) Pharmacodynamic and pharamco-kinetic aspects on the transport of bronchodilator drugs through the tracheal epithelium of the guinea pig. Pharmacol Toxicol 64:58-63.

Jongejan RC, de Jongste JC, Van Strik R, Raatgeep HC, Bonta IL. Kerrebin KF (1988) Measurements of human small airway smooth muscle function in vitro: Comparison of bronchiolar strips and segments. I Pharmacol Metho 20:135-142.

Jongejan RC, de Jongste JC, Raatgeep HC, Stijnen T, Bonta IL, Kerrebijn KF (1991) Effect of epithelial denudation, inflammatory mediators and mast cell activation on the sensitivity of isolated human airways to methacholine. Eur $J$ Pharmacol 203: $187-194$

Juniper EF, Frith PA, Hargreave FE (1981) Airway responsiveness to histamine and methacholine: Relationship of minimum treatment to control of symptoms of asthma. Thorax 36:575-579.

Kapanci $Y$, Assimacopoulos A, Irle C, Zwahlen A, Gabbiani G (1974) Contractile interstitial cells in pulmonary alveolar septa: A possible regulator of ventilation/perfusion ratio? $J \mathrm{Cell} \mathrm{Biol} 60$ : $375-392$.

Kleinstiver PW, Eyre P (1980) The lung parenchyma strip preparation of the cat and dog: Responses to anaphylactic mediators and sympathetic bronchodilators. Res Commun Chem Pathol Pharmacol 27:451-467.

Krebs HA, Henseleit K (1932) Untersuchungen über die Harnstofbildung im Tierkörper. Z Physiol Chem 210:33-66.

Krebs HA (1950) Body size and tissue respiration. Biochem Biophys Acta 4:249-269.

Krieglstein G. Krieglstein J. Urban W (1972) On the interaction of various drugs with synthetic materials used in pharmacological apparatus. Arzneimittel-Forsch (Drug Res) 22:1538-1540.

Kröll F, Karlsson J-A, Nilsson E, Persson CGA (1986) Lung mechanics of hte guinea pig isolated perfused lung. Acta Physiol Scand 128:1-8

Kroll F, Karlsson J-A, Persson CGA (1987) Tracheobronchial microvessels perfused via the pulmonary artery in guinea pig isolated lungs. Acta Physiol Scand 129:445-446.

Lei Y-H, Barnes PJ, Rogers DF (1993) Regulation of NANC neural bronchoconstriction in vivo in the guinea pig: Invoivement of nitric oxide, vasoactive intestinal peptide and soluble guanylyl cyclase. Br J Pharmacol 108:228-235.

Levey S, Gast R (1966) Isolated perfused rat lung preparation. $J$ Appl Physiol 21:313-316.

Li CG, Rand MJ (1992) Evidence that part of the relaxant response of guinea pig trachea to electrical field stimulation is mediated by nitric oxide. Br J Pharmacol 102:91-94.

Locke FS (1901) Die Wirkung der Metalle des Blutplasmas und verschiedener Zucker auf das isolierte Säugethierherz. Zbl Physist 14:670-672.

Lockhart A, Dihn-Xuan AT, Regnard J, Cabanes L, Matran R (1992) Fffect of airway blood flow on airflow. Am Rev Respir Dis 146: S19-S23.

Lulich KM, Mitchell HW, Sparrow MP (1976) The cat lung strip as an in vitro preparation of peripheral airways: A comparison of $\beta$-adrenoceptor agonists, autacoids and anaphylactic challenge on the lung strip and trachea. Br $J$ Pharmacol 68:633-636.

Madara JL. Stafford J (1989) Interferon- $\gamma$ directly affects barrier function of cultured intestinal epithelial monolayers. I Clin Invest $83: 724-727$. 
Maloney JE, Bergel DH, Glazier JB, Hughes JMB, West JB (1968) Transmission of pulsatile blood pressure and flow through the isolated lung. Circ Res 23:11-24.

Mansour S, Daniel EE (1986) Maintenance of tone role of arachidonate metabolites and effects of sensitization in guinea pig trachea. Can J Physiol Pharmacol 64:1096-1103.

McDonald JW, Heffner JE (1991) Eugenol causes oxidant-mediated edema in isolated perfused rabbit lungs. Am Rev Respir Dis 143: 806-809.

McNamara AE, Müller NL, Okazawa M, Arntorp J, Wiggs BR, Paré PD (1992) Airway narrowing in excised canine lungs measured by high-resolution computed tomography. $J$ Appl Physiol 73: $307-316$.

Michelson MJ, Shelkovnikov SA (1976) Isotonic and isometric responses of different tonic muscles to agonists and antagonists. Br J Pharmacol 56:457-467.

Michoud N-C, Paré PD, Boucher R, Hogg JC (1978) Airway responses to histamine and methacholine in Ascaris suum-allergic rhesus monkeys. J Appl Physiol 45:846-851.

Mirbahar KB, Eyre P(1980) Bovine lung parenchyma strip has both airway and vascular characteristics: Pharmacologic comparisons with bronchus, pulmonary artery, and vein. Res Commun Chem Pathol 27:451-457.

Mitchell HW, Willet KE, Sparrow MP (1989) Perfused bronchial segment and bronchial strip: Narrowing vs. isometric force by mediators. J Appl Physiol 66:2704-2709.

Montefort S, Herbert CA, Robinson C. Holgate ST (1992) The bronchial epithelium as a target for inflammatory attack in asthma. Clin Exp Allergy 22:511-520.

Moreno RH, Hogg JC, Paré PD (1986) Mechanisms of airway narrowing. Am Rev Respir Dis 133:1171-1180.

Moreno RH, Paré PD (1989) Intravenous papain-induced cartilage softening decreases preload of trachael smooth muscle. $J$ Appl Physiol 66:1694-1698.

Motojima S, Frigas E, Loegering DA, Gleich GJ (1989) Toxicity of eosinophil cationic proteins for guinea pig tracheal epithelium in vitro. Am Rev Respir Dis 139:801-805.

Munakata M, Mitzner W, Menkes H (1988) Osmotic stimuli induce epithelial-dependent relaxation in the guinea pig trachea. $J$ Appl Physiol 64:466-471.

Munakata M, Mitzner W (1991) The protective role of the epithelium. In The Airway Epithelium: Physiology, Pathophysiology, and Pharmacology. Eds., SG Farmer and DWP Hay. New York: Marcel Dekker Inc., 545-564.

Niemeier RW, Bingham E (1972) An isolated perfused lung preparation for metabolic studies. Life Sci 11:807-820.

Nijkamp FP, Folkerts G (1987) Reversal of arachidonic acid-induced guinea pig tracheal relaxation into contraction after epithelium removal. Eur J Pharmacol 131:315-316.

Okazawa M, Paré PD, Road J (1990) Tracheal smooth muscle mechanics in vivo. J Appl Physiol 68:209-219.

Omari II, Sparrow MP, Mitchell HW (1993) Responsiveness of human isolated bronchial segments and its relationship to epithelial loss. Br J Clin Pharmacol 35:357-365.

Omini C, Hernandez A, Zuccari G, Clavenna G, Daffonchio L (1990) Passive cigarette smoking exposure induces airway hyperreactivity to histamine but not to acetylcholine in guinea pigs. Pulm Pharmacol 3:145-150.

Orchck J, Douglas JS, Bouhuys $\Lambda$ (1975) Contractile responses of guinea pig trachea in vitro: Modification by prostaglandin synthesis-inhibitory drugs. $J$ Pharmacol Exp Ther 194:554-564.

Paterson G (1965) The response to transmural stimulation of isolated arterial strips and its modification by drugs.J Pharm Pharmacol $17: 341-349$.

Paton WDM (1955) The response of the guinea pig ileum to electrical stimulation by coaxial electrodes. I Physiol (London) 127 40-41P.

Patterson R (1958) The tracheal strip: Observations on the response of tracheal muscle. $J$ Allergy 29:165-172.

Pelissier T, Miranda HF, Bustamante D, Paeile C, Pinardi G (1992) Removal of the endothelial layer in perfused mesenteric vascular bed of the rat. $J$ Pharmacol Toxicol Meth 27:41-44.

Persson CGA, Ekman M (1976) Contractile effects of histamine in large and small respiratory airways. Agents Actions 6:389-393.

Persson CGA (1986) Role of plasma exudation in asthmatic airways. Lancet ii:1226-1229.

Raeburn D, Hay DWP, Farmer SG, Fedan JS (1986a) Epithelium removal increases the reactivity of human isolated tracheal muscle to methacholine and reduces the effect of verapamil. Eur $J$ Pharmacol 123:451-453.

Raeburn D, Roberts JA, Rodger IW, Thomson NC (1986b) Agonistinduced contractile responses of human bronchial muscle in vitro: effects of $\mathrm{Ca}^{2+}$ removal, $\mathrm{La}^{3+}$ and PY 108068. Eur J Pharmacol 121:251-255.

Richardson J, Béland J (1976) Nonadrenergic inhibitory nervous system in human airways. $J$ Appl Physiol 41:764-771.

Ringer $S$ (1883) A further contribution regarding the influence of the different constituents of the blood on the contractions of the heart. J Physiol (Lond) 4:29-42.

Rosa LM, McDowell RJS (1951) The action of the local hormones on the isolated human bronchus. Acta Allergol 4:293-304

Ross BD (1972) Perfusion Techniques in Biochemistry. Oxford: Clarendon Press.

Ryrfeldt $\AA$, Nilsson $E$ (1978) Uptake and biotransformation of ibuterol and terbutaline in isolated perfused rat and guinea pig lungs. Biochem Pharmacol 27:301-305.

Saga T, Said S (1984) Vasoactive intestinal peptide relaxes isolated strips of human bronchus, pulmonary artery and lung parenchyma. Trans Assoc Am Physicians 97:304-310.

Schabert A, Bauer RD, Busse R (1980) Photoelectric device for the recording of diameter changes in opaque and transparant blood vessels in vitro. Pflügers Arch 385:239 -242.

Schellenberg RR, Foster A (1984) In vitro responses of human asthmatic airway and pulmonary vascular smooth muscle. Int Arch Allergy Appl Immunol 75:237-241.

Schimassek H (1962) Perfusion of isolated rat liver with a semisynthetic medium and control of liver function. Life Sci 1:629-634.

Sekizawa K, Caughey GH, Lazarus SC, Gold WM, Nadel JA (1989) Mast cell tryptase causes airway smooth muscle hyperresponsiveness in dogs. J Clin Invest 83:175-179.

Sloviter HA, Petkovic M, Ogoshi S, Yamada H (1969) Dispersed fluorochemicals as substitutes for erythrocytes in intact animals. J Appl Physiol 27:666-668.

Snapper JR (1986) Large animal models of asthma. Am Rev Respir Dis 133:351-352.

Sparrow MP, Mitchell HW (1991) Modulation by the epithelium of the extent of bronchial narrowing produced by substances perfused through the lumen. Br J Pharmacol 103:1160-1164.

Sparrow MP, McFawn PK, Omari TI, Mitchell HW (1992) Activation of smooth muscle in the airway wall, force production, and airway narrowing. Can J Physiol Pharmacol 70:607-614.

Stephens NL, Van Niekerk W (1977) Isometric and isotonic contractions in airway smooth muscle. Can J Physiol Pharamcol 55: 833-838.

Tamaoki J, Kondo M, Takizawa T (1989) Adenosine-mediated cyclic AMP-dependent inhibition of ciliary activity in rabbit tracheal epithelium. Am Rev Respir Dis 139:441-445.

Taylor SM, Paré PD, Schellenberg RR (1984) Cholinergic and nonadrenergic mechanisms in human and guinea pig airways. 3 Appl Physiol 56:958-965. 
Taylor SM, Paré PD, Armour CL, Hogg JC, Schellenberg RR (1985) Airway reactivity in chronic obstructive pulmonary disease; failure of an in vivo methacholine responsiveness to correlate with cholinergic, adrenergic, or nonadrenergic responses in vitro. Am Rev Respir Dis 132:30-35.

Tesfamariam B, Halpern W, Osol G (1985) Effects of perfusion and endothelium on the reactivity of isolated resistance arteries. Blood Vessels 22:301-305.

Todo G, Herman PG (1986) High-resolution computed tomography of the pig lung. Invest Radiol 19:394-398.

Trendelenburg $\mathrm{P}$ (1912) Physiologische und pharmakologische Untersuchungen an der isolierten Bronchialmuskulatur. $N S$ Arch Exp Pathol 69:79-107.

Tyrode MV (1910) The mode of action of some purgative salts. Arch Pharmacodyn 20:205-223.

Vincenc KS, Black JL, Yan K, Armour CL, Donnely PD, Woolcock AJ (1983) Comparison of in vivo and in vitro resopnses to histamine in human airways. Am Rev Respir Dis 128:875-879.

Wang PM, Fike CD, Kaplowitz MR, Brown LV, Ayappa I, Jahed M, Lai-Fook SJ (1992) Effect of lung inflation and blood flow on capillary transit time in isolated rabbit lungs. $J$ Appl Physiol 72: 2420-2427.

Wanner A, Abraham WM (1982) Experimental models of asthma. Lung 160:231-243.

Weibel ER (1979) Practical methods for biological morphometry. In Sterological Methods, Vol. 1. London: Academic Press.

Weibel ER (1991) Design and morphometry of the pulmonary gas exchanger. In The Lung: Scientific Foundations. Eds., RG Crystal and JB West. New York: Raven Press. Ltd., 741-755.
Welsh MJ, Shasby DM, Husted RM (1985) Oxidants increase paracellular permeability in a cultured epithelial cell line. I Clin Invest 76:1155-1168.

West JB, Dollery CT, Naimark A (1964) Distribution of blood flow in isolated lung: Relation to vascular and alveolar pressures. $J$ Appl Physiol 19:713-724.

Whicker SD, Armour CL, Black JL (1988) Responsiveness of bronchial smooth muscle from asthmatic patients to relaxant and contractile agonists. Pulmon Pharmacol 1:25-31.

Widdicombe J (1992) Anatomy and physiology of the airway circulation. Am Rev Respir Dis 146:S3-S7.

Williams CJB (1840) Report of experiments on the physiology of the lungs and air-tubes. British Association for the Advancement of Science: Report of the Annual Meeting, Glasgow, 411-420.

Wyse DG (1977) Alteration of exogenous norepinephrine caused by electrical field stimulation and its role in poststimulant relaxation. Can J Physiol Pharmacol 55:990-1000.

Yager J, Chen T-M, Dulfano MJ (1978) Measurement of frequency of ciliary neats of human respiratory epithelium. Chest 73:627-633.

Yan K, Salome CM, Woolcock AJ (1985) Prevalence and nature of bronchial hyperresponsiveness in subjects with chronic obstructive pulmonary disease. Am Rev Respir Dis 132:25-29.

Yang Z, Diederich D, Schmeider K, Siebenmann R, Stulz P, Von Segesser L, Turina M, Bühler FR, Lüscher TF (1989) Endothelium-derived relaxing factor and protection against contractions induced by histamine and serotonin in the human internal mammary artery and the saphenous vein. Circulation 80:1041-1048.

Yang J, Mitzner W, Hirshman C (1991) Role of the epithelium in airway smooth muscle responses to relaxant agonists. $J$ App Physiol 71:1434-1440. 